\title{
Announcements
}

\section{Election of New Chairperson}

Following the recent death of Michael Petry, the position of Chair of the HSGB is now vacant. It was agreed at the 2003 AGM that nominations would be invited for a new Chairperson, with elections to be held if more than one nomination is made.

Members of the HSGB are all hereby invited to submit nominations to the Secretary of the HSGB: Dr Alison Stone, Institute for Environment, Philosophy and Public Policy, Furness College, Lancaster University, Lancaster LA1 4YG; a.stone@lancaster.ac.uk. Nominations should be submitted by $7^{\text {th }}$ May 2004 .

Where possible we would like members to vote using e-mail, to speed up the process. If we do not yet have your e-mail address, but you would like to vote, please send in your e-mail address to the Secretary. (To check whether we have your e-mail address, see the HSGB web-site: http://www.shef.ac.uk/misc/groups/hsgb/members.html) If you do not use e-mail, but would like to vote by post, please give your name and postal address to the Secretary. If we do not have your e-mail address by $7^{\text {th }}$ May and you have not informed the Secretary that you would like to vote by post, then you will not be informed of the nominees and will not be able to vote.

If there is more than one nominee, members will be given a list of nominees in mid-May, and will be invited to vote by $15^{\text {th }}$ June. The person elected as Chair will be announced shortly thereafter. 


\section{BULLETIN OF THE HEGEL SOCIETY OF GREAT BRITAIN}

\section{The Hegel Society of Great Britain}

\section{Graduate Essay Prize}

The Hegel Society of Great Britain is pleased to announce the winner of the 2003 Graduate Essay Prize. The winning essay was submitted by Oran Moked (Columbia University) and is entitled "The Relation between Religion and State in Hegel's Thought".

The judges also decided to award prizes to the essays placed joint second in the competition. These two essays were "Is Hegel a Retributivist?" submitted by Thom Brooks (University of Sheffield) and "The Role of Modern Irony in Hegel's Philosophy of Right" submitted by David James (University of Sussex). The winner receives $£ 200$ and the runners up receive $£ 100$ each. All three essays will be published (with the permission of the authors) in future issues of the Bulletin of the Hegel Society of Great Britain.

Sixteen essays were submitted to the competition and were read by a panel of five judges. The Hegel Society of Great Britain would like to thank the judges and all those who submitted essays to the competition. The judges remarked on the high quality of the submissions. We hope that the contributors also found the process of writing the essays to be rewarding. 